\title{
Toxicity Due to Arsenic in Gangetic Zone of Patna, India and Its Linkage with Cancer
}

Akhileshwari Nath*, Priyanka S E Vendan, Shailendra Kumar, Arun Kumar and J K Singh

Research Centre, Mahavir Cancer Institute, Patna, Bihar, India

\begin{abstract}
Arsenic (As), a well-known environmental toxicant naturally found in rocks in the earth's crust contaminates groundwater. Patna, a highly populated district of Bihar, India, is situated on the banks of the river Ganges in the area commonly referred to as the Gangetic-Zone. The entire district of Patna is divided into 23 blocks. The purpose of this study was to assess the concentration of As in drinking water and blood samples of people residing in different blocks of Patna.

Drinking water and blood samples were collected from all 23 blocks of Patna. Estimation of As in water samples was done using Arsenic Kit. The observed value was further validated using Atomic Absorption Spectrophotometry with Vapor Generation Assembly (AAS-VGA). More than $50 \mathrm{ppb}$ of As was observed in drinking water samples of 15 blocks (Athmalgola, Bakhtiyarpur, Barh, Belchhi, Bikram, Bihta, Daniyawan, Dulhin Bazaar, Fatuha, Ghoswari, Khusrupur, Maner, Mokama, Paliganj and Pandarakh). A concentration of more than $100 \mathrm{ppb}$ of As was detected in the samples from Danapur and Naubatpur, which is more than 10 times the WHO permissible limit of $10 \mathrm{ppb}$. Sample population exhibited high incidence of cancers of various organs such as skin, breast, liver, and gall bladder. Nodular keratosis on palm and sole of the affected population was also observed. As contamination was not observed in the blood samples of healthy people included in the study.

The study showed that surveyed population of blocks of Patna district with high As accumulation in groundwater had a high accumulation of As in their blood samples. High incidence of cancers of skin, liver, breast and gall bladder was also observed in these blocks. The study therefore demonstrates a high degree of correlation between elevated groundwater As concentration and high As concentration in blood stream of persons affected by cancer. The study further concludes that As accumulation is one of the factors causing high rate of cancer in affected areas.
\end{abstract}

Keywords: Arsenic; Toxicity; Breast cancer; Skin cancer; Drinking water

\section{Introduction}

Arsenic (As), a heavy metal, is a natural pollutant, toxin and carcinogen. It is generally found in rocks of the earth's crust in varying concentrations. Natural leaching from rocks results in dissolution of As in groundwater, however, the cause of elevated As contamination of groundwater is not known. Human beings are more vulnerable to As toxicity in groundwater as opposed to surface or shallow water due to their biochemical changes.

As is a non-essential element for human beings. According to the World Health Organization (WHO), the safe level of As in blood is less than $1 \mathrm{ppb}$. The level of toxicity depends on the chemical form of As in the environment. Arsenite and arsenate are the predominant forms found in groundwater; however arsenite is more toxic than arsenate. In groundwater, $\mathrm{As}$ is present in various forms such as $\mathrm{H}_{3} \mathrm{AsO}_{3}, \mathrm{H}_{2} \mathrm{AsO}_{3}$, $\mathrm{HAsO}_{3}, \mathrm{H}_{3} \mathrm{AsO}_{4}, \mathrm{H}_{2} \mathrm{AsO}_{4}$ and $\mathrm{HAsO}_{4}$ [1]. The concentration of As in groundwater varies with geographical location. One of the toxic forms of $\mathrm{As}, \mathrm{H}_{3} \mathrm{AsO}_{3}$, is more prominent in West Bengal (India) and Bangladesh, however $\mathrm{HAsO}_{4}$ and $\mathrm{H}_{2} \mathrm{AsO}_{4}$ are more prominent in Arizona (USA) and Korea respectively [1].

A wide range of As related human illnesses have been reported across various parts of the world. Several methods for removing As from groundwater are available but they are more amenable to industrial usage. There is no easily usable solution for As removal for individual end consumers. The incidence of As related health issues is steadily rising, particularly in the Ganges-Brahmaputra region of northern India.

Patna, located to south of the Ganges river basin (Figure 1) is one of the highly populated areas of the state of Bihar. Widespread As contamination along the course of the Ganges is well known $[2,3]$. Ganges courses through the states of Uttarakhand, Uttar Pradesh, Bihar and West Bengal in India. Based on the hydrogeological pattern of the groundwater of Ganges, the population of these states is at a high risk of As exposure and its ensuant deleterious effects [4].

The concentration of As in the groundwater of the Ganges river basin was reported to be around $50 \mathrm{ppb}$, which denotes its toxicity [5]. Groundwater and surface water are the main sources of drinking water of this region with groundwater being the prominent source for As exposure. Use of As contaminated water in northern India is alarming. Deep investigation of the effects of As contamination from a toxicological and epidemiological perspective is imperative. The district of Patna was marked as one of the As hotspot regions in Bihar [4]. The primary source of As contamination in the populace is ground and surface water. The secondary source of arsenic is consumption of food cultivated in As rich soil irrigated with As contaminated water [6]. To manage the human health hazard associated with As pollution and toxicity, data on the levels of As contamination in the environment is

*Corresponding author: Akhileshwari Nath, Research Centre, Mahavir Cancer Institute, Patna, Bihar, 801505, India, E-mail: anpgmcs@gmail.com

Received July 24, 2013; Accepted September 23, 2013; Published September 27, 2013

Citation: Nath A, Vendan PSE, Kumar S, Kumar A, Singh JK (2013) Toxicity Due to Arsenic in Gangetic Zone of Patna, India and Its Linkage with Cancer. J Environ Anal Toxicol 3: 192. doi: 10.4172/2161-0525.1000192

Copyright: (c) 2013 Nath A, et al. This is an open-access article distributed under the terms of the Creative Commons Attribution License, which permits unrestricted use, distribution, and reproduction in any medium, provided the original author and source are credited. 
Citation: Nath A, Vendan PSE, Kumar S, Kumar A, Singh JK (2013) Toxicity Due to Arsenic in Gangetic Zone of Patna, India and Its Linkage with Cancer. J Environ Anal Toxicol 3: 192. doi: 10.4172/2161-0525.1000192

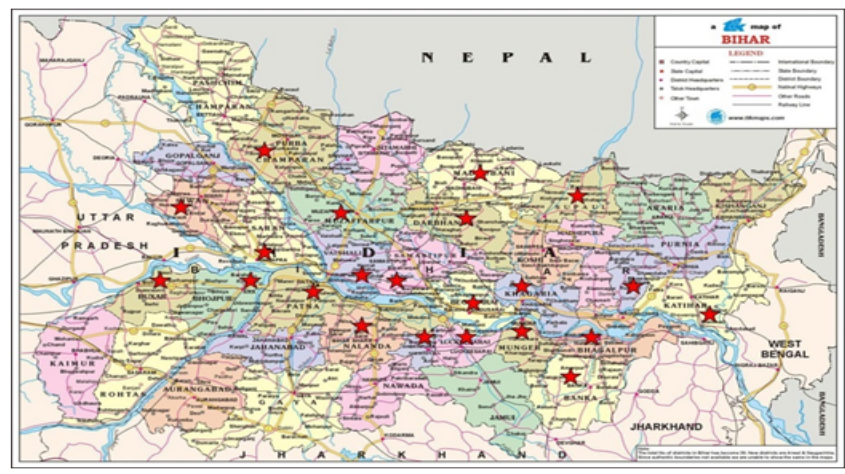

1. Banka, 2. Begusarai, 3. Bhojpur, 4. Buxar, 5. Darbhamga, 6. Katihar, 7. Khagaria, 8. Lakhisarai, 9. Muzaffarpur, 10. Nalanda, 11. Patna, 12. Purnea 13. Samstipur, 14. Saran, 15. Shekhpura, 16. Siwan, 17. Vaishali and 18. Eas Champaran

Figure 1: Hot spot districts ( ${ }^{*}$ marked $)$ in the state of Bihar.

needed. The goal of this work is to estimate the level of As concentration in drinking water and blood samples from the populace of the different blocks of Patna.

\section{Materials and Methods}

The drinking water samples were collected from different blocks of Patna District in the state of Bihar. Water samples were randomly collected from different groundwater sources (hand pump, tube well and dig well) used by households. This was done for each of the 23 blocks. 40 water samples from each of the 23 blocks were collected twice for a total of 1840 samples. Out of the 1840 water samples, samples which showed high percentage of As in estimates using the As kit were further confirmed by Atomic Absorption Spectrophotometer (minimum of 20 samples from each block). Blood samples were collected from people living in these blocks with their consent and as per ethical norms. 40 samples from each block for a total of 920 blood samples ( $5 \mathrm{ml}$ each) were collected in a vacutainer. After centrifugation, serum samples were stored at $-800 \mathrm{C}$ for evaluation of As content using Atomic Absorption Spectrophotometer. All water samples were kept in polyethylene bottles prewashed with Hydrochloric acid. Sodium arsenate was used as positive control and double distilled water was used as negative control for each block. Water samples were analyzed for arsenic using standard Merck (Germany) arsenic test kit (detectable limit from 5 to $500 \mathrm{ppb}$ based on color appearance from mild yellowish to darkish brown after the chemical reaction), which provided an approximate data set. This was done on the spot in triplicate for each sample. The results were then confirmed using AAS. Ethical approval for collection of blood samples from the sample population was requested and obtained with their consent.

\section{Results}

In eastern zone of Patna nearly $50 \mathrm{ppb}$ of arsenic content was recorded in drinking water samples. In western zone major areas were contaminated with more than $50 \mathrm{ppb}$ and a maximum of $180 \mathrm{ppb}$ was recorded by AAS method (Figure 2 and 3). When compared to WHO permissible limit, 5 fold and 10 fold increases of arsenic contamination was recorded in the target regions.

The distribution of arsenic concentration in different blocks of Patna is shown in Figure 4.

More than $1600 \mathrm{ppb}$ level of arsenic in the groundwater of Patna

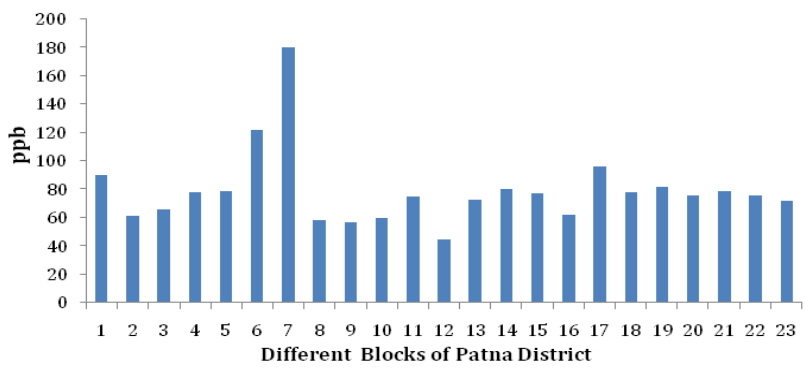

1=Maner, 2=Bihta, 3=Bikram, 4=Dulhin Bazaar, 5=Paliganj, 6=Danapur 7=Naubatpur, 8=Punpun, 9=Musarhi, 10=Phulwarisharif, 11=Sampatchak 12=Dhanarua, 13=Patna sadar, 14=Fatwah, 15=Daniyawan, 16= Khusrupur 17= Bakhtiarpur, 18=Athamalgola, 19=Barh, 20=Belchhi, 21=Pandarak 22=Mokama, 23=Ghoswari

Figure 2: Arsenic contamination in drinking water of different blocks of Patna, India.

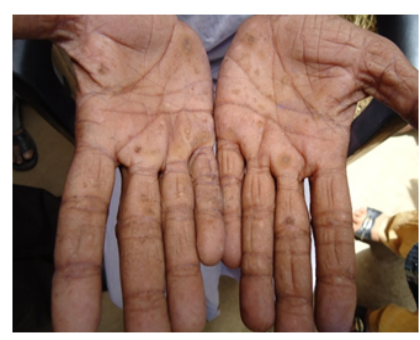

(A)

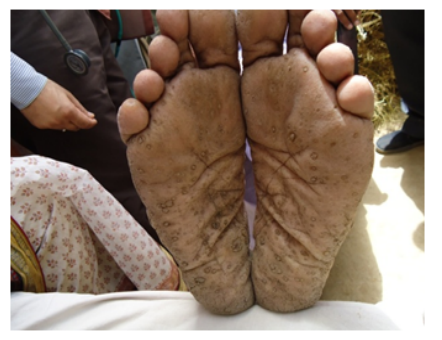

(B)
Figure 3: Showing nodular keratosis on palm $(A)$ and sole $(B)$.

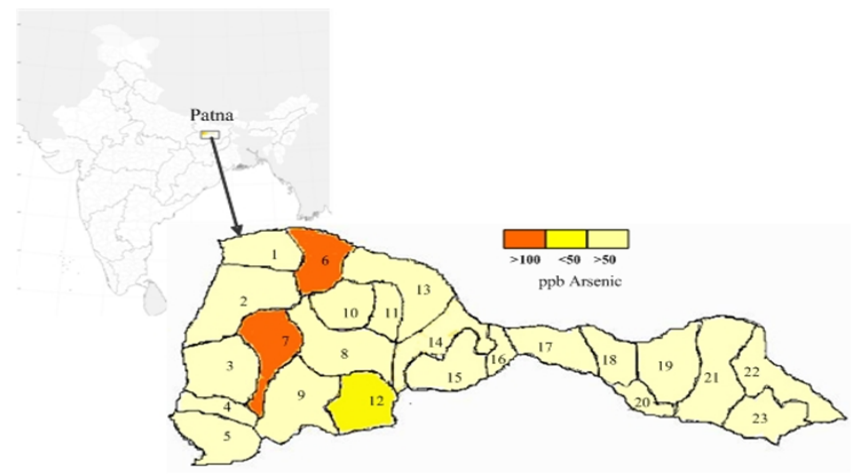

1-Maner; 2-Bihta; 3-Bikram; 4-Dulhin Bazar; 5-Paliganj; 6-Danapur 7-Naubatpur; 8-Punpun; 9-Masaurhi; 10-Phulwarisharif; 11-Sampatchak; 12-Dhanarua; 13-Patna Sadar; 14-Fatwah; 15-Daniawan; 16-Khusrupur 17-Bakhtiarpur; 18-Athmalgola; 19-Barh; 20-Belchhi; 21-Pandarak 22-Mokama; 23-Ghoswari

Figure 4: Arsenic concentration in $p p b$ in different blocks of Patna district ( $>50 \mathrm{ppb}$ to $<100 \mathrm{ppb}$ ).

region by AAS method has been also reported [7]. Arsenic contaminated drinking water is one of the major risk factor for cancer [8-10].

The total population of Patna district is about 5.7 million [11] Approximately 59\% of the total population of Patna region lives in arsenic hit region (Figure 5).

Maximum mean level of arsenic was detected in the blood samples of gall bladder cancer ( $25 \mathrm{ppb})$ patients followed by liver, skin and breast cancer patients (Figure 6). Higher concentration of arsenic 
Citation: Nath A, Vendan PSE, Kumar S, Kumar A, Singh JK (2013) Toxicity Due to Arsenic in Gangetic Zone of Patna, India and Its Linkage with Cancer. J Environ Anal Toxicol 3: 192. doi: 10.4172/2161-0525.1000192

Page 3 of 10

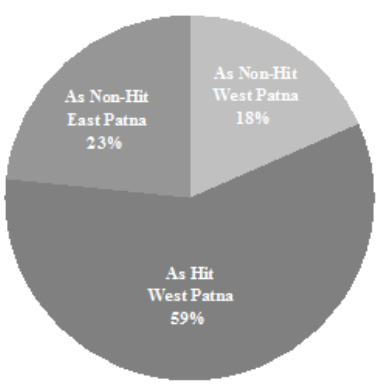

Figure 5: Percentage of human population in arsenic hit and non-hit regions in Patna, India.

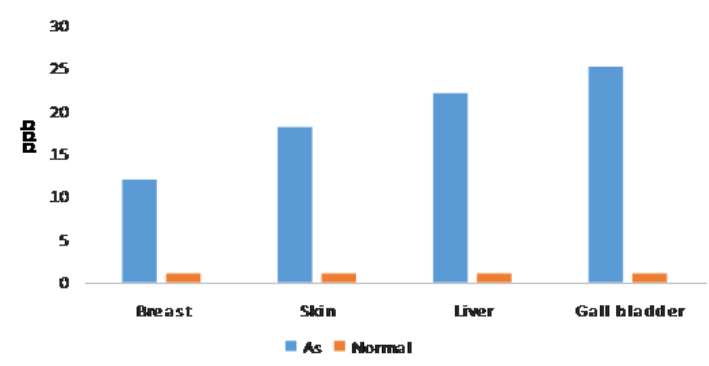

Figure 6: Mean residual level of arsenic in the blood of different cance patient of the Gangetic-Zone of Bihar.

was observed in west blocks of Patna compared to east blocks, India. The highest concentration of arsenic was observed in Danapur and Naubatpur block of Patna.

\section{Discussion}

In Bihar 60 persons with arsenical skin lesions were reported [2]. According to US National Research Council (NRC), more than 50 $\mathrm{ppb}$ of arsenic in groundwater may cause cancer risk in 1 out of 100 of individuals [12]. Prevalence of prostate cancer was linked to the arsenic hotspot regions in Gangetic-zone of Bihar [13]. Apart from cancer risks, other researchers have reported occurrences of arsenicosis (arsenic related toxicities) in the population of northern India. Among cancer patient from the different blocks of Patna arsenic concentration in the blood samples was recorded over the WHO permissible limit. High levels of arsenic in the blood samples from people of Ballia district, Uttar Pradesh was also reported by All India Institute of Medical Sciences, New Delhi [11]. Ingestion of arsenic via drinking water for longer duration (1-10 years) is associated with skin lesions, which finally develop into adenoidcystic carcinoma. Similar results have been reported by other researchers [9]. In addition, patients with more than $40 \mathrm{ppb}$ of arsenic for 2 to 5 years also show squamous cell carcinoma and basal cell carcinoma.

One of the main regions of arsenic contamination in the Gangetic region of Bihar may be due to degradation of rocks of northern Himalaya region, which along with the soil and sediment in the Ganga ultimately get accumulated in the Gangetic zone over the years. It is highly probable that this is the reason that high level of arsenic reported in Bangladesh [14]. Highly urbanized regions consume more groundwater than the rural regions by digging more wells.
Accordingly, population density including the digging wells could possibly be related to high concentration of arsenic contamination in Patna region. Populace of this region should be aware of the presence of high concentration of arsenic in groundwater and should use potable surface water rather than groundwater. Scientific investigators and environmentalists should also assess the status of arsenic pollution and related public health impacts in northern India. By the way of using healthy diet and safe water, people can protect themselves from arsenic chronic toxicity. Long-term exposure to inorganic arsenic is linked with certain forms of cancer such as skin, liver, breast and gall bladder cancer. Other researchers have also reported the correlation of exposure to arsenic and cancers [10].

In this study it was observed that high incidences of breast, skin, liver, and gall bladder cancers were recorded in arsenic hit area. A significant correlation was found between the cancer incidence and groundwater arsenic level. It is therefore concluded that As concentration is one of the factors leading to an elevated risk of occurrence of cancer.

\section{Acknowledgement}

We are grateful to the Department of Science \& Technology (DST), Ministry of Science \& Technology, Govt. of India, New Delhi for financial support. The authors are also thankful to IITR Lucknow India and Dept. of Environment and Water Management, A. N. College, Magadh University, Bihar, India.

\section{References}

1. Saxena VK, Sanjeev KM, Singh VS (2004) Occurrence, behavior and speciation of arsenic in groundwater. Curr Sci 86: 281-284.

2. Chakraborti D, Mukherjee SC, Pati S, Sengupta MK, Rahman MM, et al. (2003) Arsenic ground water contamination in Middle Ganga Plain, Bihar, India: future danger. Environ Health Perspective 111: 1194-201.

3. Ghosh AK, Singh SK, Bose N, Chaudhary S (2007) Arsenic contaminated aquifers: a study of the Ganga levee zones in Bihar, India. Annual Conference 2007, Royal Geographical Society, London.

4. Sahu KC (2002) Arsenic poisoning in the Gangetic delta: An anthropogenic model. Curr Sci. 83: 21-22.

5. Mukherjee A, Sengupta MK, Hossain MA, Ahmed S, Das B, et al. (2006) Arsenic contamination in groundwater: A global perspective with emphasis on the Asian scenario. Journal of Health Population and Nutrition 24: 142-163.

6. Hughes MF (2002) Arsenic toxicity and potential mechanisms of action. Toxicol Lett 133: 1-6.

7. Saha D (2009) Arsenic groundwater contamination in parts of middle Ganga plain, Bihar. Curr Sci 97: 753-755.

8. Smith AH, Hopenhayn RC, Bates MN, Goeden HM, Hertz PI, Duggan, et al (1992) Cancer risks from arsenic in drinking water. Environ Health Persp 97: 259-267.

9. Yu RC, Hsu KH, Chen CJ, Froines JR (2000) Arsenic Methylation Capacity and Skin Cancer. Cancer Epidemiology, Biomarkers \& Prevention 9: 1259-1262.

10. Gbaruko BC, Ana GREE, Nwachukwu JK (2008) Ecotoxicology of arsenic in the hydrosphere: Implications for public health. Afr. J.Biotechnol 7: 4737-4742.

11. Coleridge ST (2005) Arsenic - India's health crisis attracting global attention Current Science 88: 683-684

12. Ahmad J, Goldar BN, Misra S, Jakariya M (2003) Willingness to pay for arsenic free, safe drinking water in Bangladesh. World Bank Water and Sanitation Program South Asia.

13. Nath A, Singh JK, Ezhil VS, Priyanka, Sinha S (2012) Elevated level of prostate specific antigen among prostate cancer patients and high prevalence in Gangetic zone of Bihar, India. Asian Pacific Journal of Cancer Prevention 13: 221-223.

14. Tondel M, Rahman M, Magnuson A, Chowdhury IA, Faruquee MH, et al. (1999) The Relationship of Arsenic Levels in Drinking Water and the Prevalence Rate of Skin Lesions in Bangladesh. Environ Health Perspect 107: 727-729. 